that any remaining bacteria are easily dislodged from the surface. With satisfactory washing it is possible to achieve a high degree of sterility by immersing the articles for a much shorter time in the rinse water than would be required if all the bacteria remained attached to the surface.

The United States Public Health Service Code requires: (1) a cleaning process with a detergent solution at $110-120^{\circ} \mathrm{F}$.; (2) sterilization (with a choice of four methods); and (3) drying with clean cloths, or preferably by evaporation. The standards required in the United States give, apparently, a very wide margin of safety if the conditions for high. temperature-short-time pasteurization, that is, $162^{\circ} \mathbf{F}$. for not less than fifteen seconds, can be taken as a guide for the destruction of pathogenic organisms. Evaporation after hot-water rinsing is preferable to drying by a cloth.

For utensils with thick or dried-on deposits, machines which allow a long period of contact with detergent solution are necessary. An important point in the design of such machines is the avoidance of excessive carry-over of the detergent solutions to the rinsing compartments.

A plant used for the preparation, service and storage of food needs the same if not more attention from the hygienic point of view than the multiservice utensils.

To obtain a bactericidal effect with steam it is essential to keep the steam in an enclosed, space with a comparatively small vent and to continue stéaming for at least three minutes after steam issues from the vent at over $205^{\circ} \mathrm{F}$.

The authors suggested that it would be sometimes advisable to employ two different types of sterilizing treatment, for example, steam and hypochlorite solution, with the object of destroying organisms which might escape one of these treatments, but no experimental evidence was quoted in support of this view. Hypochlorite treatment must, of course, be followed by further rinsing with cold water.

\section{WIGAN MINING COLLEGE}

$F$ OUNDED on October 27, 1857, Wigan and District Mining and Technical College has just celebrated its ninetieth anniversary. In its first session the average attendance was 15; now it has some 2,800 students. The intervening ninety years show a continuous record of expansion and progress in spite of many difficulties. Like most higher institutions of learning in Britain to-day, the College is overcrowded and badly in need of extended accom. modation and additional facilities, particularly for postgraduate and research work. Founded primarily to develop mining education, and still maintaining a leading position in that field, it has never confined itself to mining alone. Its range of work covers also engineering, chemistry, physics, geology, biology, mathematics, building, commerce, economics, art, and other subjects.

A special feature of the work of the College is the provision of complete full-time courses for the degrees of the University of London in mining, engineering, general science, chemistry, physics, geology, mathematics and economics. The College is inspected and recognized by the University in connexion with the mining and engineering degree courses. It is also recognized by the Board for Mining Examinations, the Board of Trade, the Institution of Civil Engineers, the Institution of Mining Engineers, the Royal Institute of Chemistry, the Institute of Physics, etc. It is the headquarters of the Manchester Geological and Mining Society and provides accommodation for meetings of many other scientific, technical and professional bodies. A notable feature of its work is the development of its library and refectory services and of student activities. It has in Christopher Park one of the finest athletic grounds in the north of England.

A meeting to celebrate the ninetieth anniversary was held in the College hall on June 7. This was attended by a very representative gathering, including educationists, scientific workers, industrialists, and government and local officials, as well as governors, staff and students. The chairman of the Governing Body, Colonel J. S. A. Walker, presided, and the principal, Dr. J. F. S. Ross, gave a brief survey of the history and work of the College, directing attention to the devoted service it had received from its founders and their successors, its longstanding regional character and independence-it receives very substantial grants from the Lancashire and Wigan Education Authorities but possesses its own freehold land and buildings and has its own autonomous governing body-and to the development within it of a truly educational and collegiate spirit. The chairman of the General Purposes Committee, County Councillor A. Guest, who has been a governor of the College for the last third of a century, also referred to aspects of its history and directed attention to its high reputation at home and abroad. Notwithstanding the invaluable help of local authorities, the College needs greater financial resources, and he thinks it should receive these on lines comparable with those on which university colleges are helped by the University Grants Committee.

Sir Charles Ellis, scientific member of the National Coal Board, gave an address on "The Place of Science in a Technical Training". After commenting on the high reputation of the College in science and industry -he had heard from everyone in a position to judge that Wigan-trained people had a sound knowledge of and lively interest in the fundamental sciences and a genuine appreciation of the means of applying them to technological problems-Sir Charles referred to the distinction between industrial scientists and research scientists, and denied the validity of any difference of status between them. He mentioned the manifold duties of scientific men in connexion with the National Coal Board : while the majority of them are in the colliery chemical services and carry out their scientific duties in daily contact with industry, there are other groups which have more national standing. He mentioned the special group dealing with the survey of coal seams in Britain, and said that we have an accurate knowledge of the quality of our coal seams for many years ahead before they are mined. He also referred to the research group engaged on fundamental studies of coal substance. These are doing pioneer work. He went on to develop a closely reasoned argument as to the intrinsic value of scientific education, not only in relation to industry but also in inculcating a genuinely philosophical attitude to life. The address is to be published by the College in pamphlet form.

An illustrated booklet on the College has been issued in connexion with the ninetieth anniversary; copies can be obtained from the College office, price 1s. $6 d$. each. 